\title{
British employment tribunals: from the side-lines to centre stage
}

Susan Corby, University of Greenwich, UK

Employment tribunals, originally called industrial tribunals, were established fifty years ago in Great Britain and this article traces their gradual change. Originally constituted as administrative tribunals in 1964, they morphed to party versus party forums from the 1970s, but this gradual change did not stop there. Over the succeeding years, employment tribunals moved from a marginal role to a central role in British employment relations, as their caseload has risen, their remit has widened, and as legal regulation has replaced collective regulation. Moreover in so doing, employment tribunals have become less accessible to workers, less speedy and more expensive. They have also become more formal, with legal norms and practices and adjudication by lawyers alone replacing industrial relations norms and adjudication by a mix of lawyers and lay people. As a result, employment tribunals have become juridified. The article concludes by critiquing the basis of employment tribunals which is the self-help/complainant after the event approach, as opposed to state enforcement of statutory employment rights.

Keywords: employment tribunals, dispute resolution, tripartism, juridification, legalism, judges, British employment relations.

\section{Introduction}

Employment tribunals, originally called industrial tribunals, were established fifty years ago in Great Britain and this article traces their development. Originally constituted as administrative tribunals, they morphed to party versus party forums from the 1970s. Over the succeeding years there has been steady incremental change and employment tribunals have moved from a marginal role to a central role in British employment relations, as their caseload has risen, their remit has widened, and as legal regulation has replaced collective regulation. As a result, employment tribunals have become more legalistic and courts in all but name: that is they have become juridified.

This article first considers the concept of juridification. After reviewing the employment relations background, it then examines employment tribunals' first decade, after which it traces their development organising this material according to the yardsticks applied to tribunals more generally: expedition, accessibility, informality, expertise and expense. It then considers another relevant matter, enforcement, before concluding that the history of employment tribunals exemplifies juridification and that the self-help/complainant approach, which is the basis of the British employment tribunal system, seems to have been accepted without any consideration of an alternative enforcement approach that is a state constituted labour inspectorate. 


\section{Juridification}

The argument of this article is that over the last 50 years employment tribunals have become barely distinguishable from the courts, essentially because of juridification and the steps that the government has taken to make users pay. Heery and Noon ${ }^{1}$ define juridification as the process of increasing legal intervention in the employment relationship, but as Simitis $^{2}$ points out, this consists not only of increases in employment legislation; the influence of the courts also contributes to juridification. Masterman ${ }^{3}$ echoes this but also adds that juridification covers 'the increased propensity of individuals and groups to see courts as the appropriate forum for the resolution of social disputes, and perhaps even simply an increased use of legal terminology in discourse'.

Blichner and Molander take this further. ${ }^{4}$ They admit that juridification is an ambiguous concept, but they argue, like Heery and Noon above, that it is a process; it is something that increases over time. If the process is reversed, there is dejuridification. They also argue that juridification has five dimensions. Their first dimension is what they call constitutive juridification, when a legal order is established, that is when an institution is obliged to follow certain rules that are precisely stated and where the final judgment is made by a third party. The second dimension of juridification is when an activity is subjected to legal regulation. The third dimension of juridification is when conflict is increasingly resolved by reference to law. The fourth dimension is increased judicial power. The fifth dimension is what they call legal framing; when there is a legal culture, and this implies a normative element. The expanded definition of Blichner and Molander is adopted here.

\section{Background}

In the first half of the $20^{\text {th }}$ century, trade union membership increased substantially from two million in 1900 to over nine million in $1950^{5}$ and the trade unions campaigned to obtain statutory protection against tort liabilities invoked by employers to limit industrial action. In the main, trade unions were able to keep the courts from intervening in labour relations and to resolve workplace disputes and grievances through collective bargaining and the implicit threat of industrial action. Moreover, trade unions' preference for collective bargaining at that

time was demonstrated, according to Dickens et $a l,{ }^{6}$ by a Trades Union Congress survey in 1961 which found that the majority of affiliated unions preferred questions of dismissal to be regulated by collective bargaining, not legislation. 
Indeed Otto Kahn Freund, considering employment relations in Britain in the 1960s, characterised it as 'collective laissez-faire' and noted that the impact of the law in the workplace was 'only a fragment' and '[a]s a power countervailing management the trade unions are much more effective than the law has ever been or can ever be'?

Kahn-Freund, however, was not prescient. First, collective regulation has waned over the last 50 years. In the UK, trade union membership reached a peak of over 13 million members and a density of 50 per cent in 1979. In the ensuing 30 years union membership and density halved, the most dramatic decline taking place in the 1980s. In 2013 there were just 6.5 million members and a density of 25 per cent, with 29.5 per cent of all employees being covered by a collective agreement in $2013 .{ }^{8}$ Furthermore, in 2011 only a third of British workplaces that had five or more employees and recognised a trade union had a lay trade union representative on site. ${ }^{9}$ This decline in trade unionism is not a purely British phenomenon. Trade union membership has declined in Western Europe, but in Britain, unlike many other European countries, collective regulation and trade union membership and density are broadly aligned, as the UK lacks any institutional supports for collective bargaining such as ergo omnes. ${ }^{10}$

Many reasons have been given for this decline in trade union density, including changes in the composition of the British economy, ${ }^{11}$ but a significant factor has been the legal curbs on British trade unions and the right to strike. ${ }^{12}$ At the same time, from the 1960 s the law, in the form of worker's individual statutory rights, has become increasingly salient in employment relations. The first major right for workers, the right to claim unfair dismissal, was introduced under the Industrial Relations Act 1971 following a recommendation from a Royal Commission aimed at reducing the number of strikes arising from dismissals, ${ }^{13}$ and reenacted under subsequent legislation when the 1971 Act was repealed,

There then followed a raft of new rights for workers in the 1970s, partly as a result of initiatives taken by the Labour government and partly as a result of the United Kingdom joining the European Union. In the 1970s these included a worker's right to maternity pay and leave, not to be discriminated in employment on the grounds of sex, marital status, race and ethnic origin, to have equal pay irrespective of gender, to be given an itemised pay statement and time off for trade union duties. In the succeeding decades, workers were given 
further statutory rights, for instance not to be discriminated on grounds of disability and later on grounds of age, sexual orientation and religion or belief, to have certain limits on working time and to be paid the minimum wage. ${ }^{14}$ As a result, increasingly workplace disputes were less likely to be resolved by trade unions at the workplace and claims to employment tribunals increased significantly, from 13,555 in 1972 (the year in which the right not to be unfairly dismissed was introduced) ${ }^{15}$ to 192,000 in 2012-13. ${ }^{16}$

In summary, collective regulation has significantly declined in the last 50 years, while workers' statutory rights have significantly increased and these two factors, taken together, have generated an upsurge in claims to employment tribunals. As a result, these tribunals have become increasingly prominent, although as we will see, this prominence was not obvious when they were first established.

\section{Early years}

The origins of industrial tribunals (as Britain's employment tribunals were called until $1998^{17}$ ) are 'shrouded in silence, if not in mystery'. ${ }^{18}$ They were 'children of civil servants' and not created at the request of employers, unions or political parties. ${ }^{19}$ This is unlike the position in France and Germany where trade unions were instrumental in the establishment of labour courts. ${ }^{20}$

From the end of World War 2, however, specialist tribunals in other areas had proliferated, so the decision to establish an employment tribunal to hear appeals against administrative decisions in the labour sphere, (rather than to require cases to be brought to the courts) was at least partially pragmatic, according to one of the first presidents of the employment tribunals:

[It] was partly due to the lack of lawyers of sufficient competence to man (sic) the judicial bench, to deal with the increase in judicial work, but enough competent lawyers could be found to be chairman of tribunals because they only had to deal with a narrow band of law and could quite quickly become expert in it. ${ }^{21}$

Employment tribunals' original jurisdiction flowed from s.12 Industrial Training Act 1964, which provided for Industrial Tribunal Regulations. Although they were to become an important institution, their establishment was hardly debated as their original jurisdiction was to hear an appeal by an employer in respect of a levy imposed by Industrial Training Boards to finance training, a relatively minor matter. For instance those on the Bill's Standing 
Committee only discussed the onus of proof on the employer making such an appeal, not the adjudicatory tribunal itself. ${ }^{22}$

The composition of employment tribunals (originally called industrial tribunals as noted above) was determined in Regulations and these were laid before Parliament on 20 May 1965. At that time the Redundancy Payments Bill was going through Parliament, so disputes in respect of the Redundancy Payments Act (RPA) 1965 were also given to the new institution without any evident thought. Although redundancy pay was an employee/employer dispute, the State had an interest because any redundancy payment made by the employer that complied with the Act was refunded to the employer by the State. Also, s.38 RPA amended the Contracts of Employment Act 1963 to provide that claims concerning the failure to give, or the accuracy of, written particulars of the main terms and conditions of employment should be removed from the jurisdiction of the criminal courts and instead be referred to employment tribunals. In 1967 there was further expansion of the remit of employment tribunals when they were given powers to adjudicate on administrative decisions in two areas: firstly, on appeals in relation to the Selective Employment Payments Act 1966, where tribunals were given authority to decide on whether a claimant had a right to repayment from the State ${ }^{23}$; and secondly under the Docks and Harbour Act 1966, where tribunals were given authority to decide whether employment was dock work for certain purposes, including the licensing of dock employment. ${ }^{24}$

It is not at all clear why these employment tribunals, which essentially were dealing with administrative decisions in the 1960s, were established on a tripartite basis from the start: a professional judge and two lay members, one appointed after nomination by the Trades Union Congress (TUC), the other appointed after nomination by the Confederation of British Industry (CBI), all three having an equal vote. As Wedderburn commented:

Why the two laymen who sat should include a union nominee for that work (deciding the meaning of "trade or industry", or whether a "business activity" was carried on by the Plas Machunlleth Fox Destruction Society) was obscure. (Original emphasis). ${ }^{25}$

Be that as it may, although employment tribunals obtained another administrative jurisdiction as a result of the Health and Safety at Work Act 1974, hearing appeals against enforcement notices, from 1972 the bulk of their work changed dramatically to adjudication on party versus party disputes, that is worker/employee on the one hand versus employer on the other. 
The notion of employment tribunals resolving all types of employee/employer disputes was suggested by the Ministry of Labour in the 1960s in its evidence to the Royal Commission on Trade Unions and Employers' Associations, often called the Donovan Commission after the Commission's chairperson. ${ }^{26}$ Instead, the Commission recommended that what it called 'labour tribunals' should be set up to adjudicate on 'all disputes arising between employers and employees arising from their contracts of employment or from any statutory claims they may have against each other in their capacity as employer and employee'. ${ }^{27}$ The Commission did not propose that these so-called labour tribunals:

.... should be given the job of resolving industrial disputes ... arising between employers or employers' associations and trade unions or groups of workers ... Nor do we envisage any matters arising between trade unions and their members or applicants for membership should be within the jurisdiction of labour tribunals ${ }^{28}$

In short, the Commission recommended that labour tribunals should not determine collective disputes, but they should determine all individual ones. In particular, the Commission recommended that they should adjudicate on its proposed right to claim unfair dismissal. As a result of that shift, employment tribunals became clearly distinguishable from other British tribunals, which continued as administrative tribunals. ${ }^{29}$

In fact, from the 1970s, as noted above, successive, governments gave employment tribunals jurisdiction to hear an individual's statutory claims, and the number of these statutory claims mushroomed.

\section{Tribunals versus courts}

The seeds of juridification were planted at the start. Employment tribunals were from the outset part of the legal system, with a qualified lawyer in the chair, evidence given on oath, cross-examination and originally appeals being made to the Queen's Bench Division of the High Court. Since 1972 there have been specialist appeal bodies at the first appellate level, the National Industrial Relations Court and then from 1976 to the present day the Employment Appeal Tribunal. Further appeals, however, could then, and can now, be made only to the higher, non-specialist civil courts: the Court of Appeal and the Supreme Court, formerly known as the House of Lords. As we will see below, this has influenced how employment tribunals have interpreted the law. 
Nevertheless, some 50 years ago tribunals were seen as distinguishable from the civil courts and, a report to Parliament from a Committee, chaired by Lord Franks, specified when tribunals, as opposed to the courts, should be used. This report said:

... preference should be given to the ordinary courts of law rather than to a tribunal unless there are demonstrable special reasons which make a tribunal more appropriate, namely the need for cheapness, accessibility, freedom from technicality, expedition and expert knowledge of a particular subject. ${ }^{30}$

The Donovan Commission broadly echoed this, essentially adopting the Franks criteria, when recommending that employment tribunals, not the civil courts, should adjudicate claims of unfair dismissal. It said that industrial tribunals (as they were then called) should provide for the parties 'an easily accessible, speedy, informal and inexpensive procedure'. ${ }^{31}$

The next part of this article traces the development of employment tribunals over the last half century, organising this first under the Franks/Donovan yardsticks and then going on to consider other matters.

\section{Speed/expedition}

Employment tribunals have become less expeditious over the years and, although the official metrics have changed and are not strictly comparable, nevertheless a broad picture emerges of less and less expedition. First, the time taken from lodging a claim to the hearing being held has increased and second, (although less dramatically) the duration of a hearing has increased. In 1978, 39 per cent of claimants said that the time elapsing from the claim to the hearing was less than 8 weeks. ${ }^{32}$ In 1988, the then current performance indicator was that at least 60 per cent of cases heard should reach a hearing within 12 weeks of the claim being lodged. In 1997, the performance indicator was 85 per cent of cases to a first hearing within 26 weeks. 'This was achieved and frequently exceeded virtually everywhere outside London, where the rate was much lower'. ${ }^{33}$ In the first quarter of 2014 the mean time from a single claim being accepted to a final judgment was 34 weeks. ${ }^{34}$

As to the duration of a hearing, in 1978, a survey found that 61 per cent of applicants and 51 per cent of respondent employers said that their hearing had lasted half a day or less. ${ }^{35}$ In 1992, a survey found that ' $[\mathrm{t}]$ he average hearing lasted between half a day and a whole 
day'. ${ }^{36}$ In 2013, a survey found that the mean length was 1.5 days. 'One in five tribunal hearings lasted more than an hour but less than a day (20 per cent). A quarter lasted a day (26 per cent) and another quarter lasted two or more days (27 per cent).${ }^{37}$ In other words, there has been an increase in the length of hearings over the last 35 years.

\section{Accessibility}

One aspect of accessibility is location. Initially employment tribunals held hearings in ad hoc venues, 'hotels, houses, libraries, council chambers, civic centres and other government accommodation', a total of 84 different locations in $1971 .{ }^{38}$ Now, like civil courts, they operate in fixed court venues and at the time of writing there were 29 employment tribunals in England, Wales and Scotland with some half dozen further hearing centres operating either temporarily or part-time. Accordingly geographical accessibility has declined.

Accessibility can also be measured in terms of the ease of making a claim. From the inception of employment tribunals up until October 2005, claims and responses were not required to be presented on designated forms and a letter could suffice, unlike in the civil courts. The only details that were required were the name and address of the claimant and/or, if different, an address to which all documents and notices were to be sent; the name and address of the person(s) against whom relief was sought; and brief details of the complaint. From October $2005^{39}$, the Government prescribed that claims and responses (ET1 and ET3 respectively) could only be lodged on designated forms, which have grown from two pages ${ }^{40}$ to 16 pages at the time of writing $(2014)^{41}$. Moreover, claims can be rejected if not all the required information is provided, with the claimant being given the opportunity to resubmit. In 2006-2007, 9 per cent of claims that were resubmitted were either not accepted or never resubmitted ${ }^{42}$, although this declined to less than one per cent in 2010-11. ${ }^{43}$ The Government, however, introduced a new ground of rejection in 2013: if a claim is 'in a form which cannot sensibly be responded to...' ${ }^{44}$ In short, the ease of making a claim has been reduced considerably over the last half century.

Finally accessibility can be measured by the ease in which a claim is accepted by an employment tribunal. Before 1980, a claim could be lodged without any screening mechanism. From 1980, however, the government introduced a procedure of pre-hearing assessments to weed out unmeritorious claims, whereby a tribunal of its own motion, or at the request of one of the parties, could filter out worthless claims, for example because the 
claimant did not have employee status. To that end, it would consider the claim form, the notice of appearance (the respondent's reply) and any other written and oral representations by the parties. If the tribunal decided that there was no prospect of success, it would warn the party and state that if that party still wished to proceed, it could do so and a differently constituted tribunal would hear the substantive case. Should the party who had already been warned lose, however, that tribunal could award costs. According to Hepple and Fredman, 'in the year ending September 1984, [pre-hearing] assessments were arranged for just over 3,000 cases, but of the 40 per cent warned, only 79 eventually had costs (at an average of $£ 136$ ) awarded against them'. ${ }^{45}$

The government amended this procedure in 1993, replacing pre-hearing assessments with pre-hearing reviews (PHRs) and deposit orders. At a PHR, if a judge, having considered written and any oral representations by the parties, decides that there is little reasonable prospect of success, he/she can require a party, who nevertheless wishes to proceed to a substantive hearing, to pay a deposit. The amount is set taking account of the party's means up to a limit. In 2013 PHRs were renamed preliminary hearings and the deposit limit was raised from $£ 500$ to $£ 1,000^{46}$. Where a deposit order is made, and the party pays it rather than withdrawing, the substantive case is heard by a different tribunal, with the deposit refunded if that party wins.

\section{Informality/freedom from technicality}

From the outset until today, employment tribunals have been more informal than the 'ordinary' courts. For instance then and now the adjudicator(s) do not wear robes, and strict rules of evidence do not apply; for instance hearsay evidence is admissible, although the tribunal might not put much weight on it. Moreover, the 2013 employment tribunal rules have for the first time as one of their overriding objectives (rule 2e), 'avoiding unnecessary formality and seeking flexibility in their proceedings'.

Nevertheless, the contention of this article is that little by little employment tribunals have become more formal and technical. First, their remit has become more intricate and technical. As we have seen employment law has grown in scope and furthermore, 'is complex and often obscure'. ${ }^{47}$ This expansion of employment law is mirrored in a compendium of employment law (which despite its size is called a 'Handbook'). It is edited by Peter Wallington QC, who noted in the introduction to the $21^{\text {st }}$ edition in 2013: 
[T] he trend over more than 30 years of the Handbook has been an inexorable increase in the volume and detail of legislation, from 558 pages in 1979 to some 5 times that now [2013], despite smaller print and less emphasis on health and safety legislation. ${ }^{48}$

This expansion of employment law is also mirrored in the growth of case law and employment law reporting, with which lawyers, but not lay people, are familiar. Because of the doctrine of precedent, tribunals must follow the rationale for the decision of the higher courts where the case concerns the same material facts, so the judgments of the higher courts are binding, and thus are closely read by lawyers, and have mushroomed. As one indicator, Industrial Relations Law Reports was first issued in September 1972 with 31 pages, after which it appeared monthly. The September 2014 issue was more than double the 1972 issue at 66 pages.

This doctrine of precedent has not only resulted in employment law becoming a complex field of study. It has also enabled judges in the appellate courts, who are familiar with common law concepts but not the workplace, to influence the way that employment tribunals interpret employment law, with the result that common law concepts have permeated the interpretation of statutes and employer prerogatives have been prioritised. For instance, in 1977 the Employment Appeal Tribunal in respect of an unfair dismissal case said: 'it is important that the operation of the legislation in relation to unfair dismissal should not impede employers unreasonably in the efficient management of their business ${ }^{49}$.

This prioritisation of employer prerogatives, however, is not entirely as a result of binding decisions by the higher courts. From the start, tribunals were reluctant to question employers' judgments on redundancy concerning 'their market assessment of the continued need for work ${ }^{50}$ or the particular selection of those made redundant. As Wedderburn later said:

[The common law] tradition still expresses a version of the civil obligations required of the servant... The archetypal models of master and servant have since 1825 run deep into the culture of judicial assumptions, including the interpretation of employment protection legislation. ${ }^{51}$

Given here are only a couple of examples to illustrate Wedderburn's point. The first example is the reasonable responses test in unfair dismissal. Under the statute, the employment tribunal must first determine what the reason for the dismissal was and, if the reason is 
potentially fair, then the tribunal has to determine 'whether the employer acted reasonably or unreasonably in treating it as a sufficient reason for dismissal' ${ }^{52}$ The House of Lords in 1977 directed the tribunal when applying this test to focus on the conduct of the employer 'and not on whether the employee in fact suffered an injustice'. ${ }^{53}$ This test was later elaborated by the Employment Appeal Tribunal when it said:

the function of the [Employment] Tribunal, as an industrial jury, is to determine whether in the particular circumstances of each case the decision to dismiss the employee fell within the band of reasonable responses which a reasonable employer might have adopted. If the dismissal falls within the band the dismissal is fair: if the dismissal falls outside the band it is unfair. ${ }^{54}$

This 'band of reasonable response' test was criticised by a later president of the Employment Appeal Tribunal in Haddon as an 'embellishment on the statute' leading tribunals into applying what amounts to a perversity test ${ }^{55}$. Similarly, a senior academic, trenchantly criticised the band of reasonable responses test and said:

The message from the courts is that employment tribunals should respect management's power to govern the business... It is reminiscent of the common law stance of wrongful dismissal, where judges refused to assess the substantive grounds for dismissal unless there had been a breach of the express terms of the contract. ${ }^{56}$

Nevertheless, despite these criticisms, the band of reasonable responses test has been reaffirmed by the highest courts, most recently in 2000 when the Court of Appeal, criticising the judgment in Haddon, said that the Employment Appeal Tribunal had made 'an unwarranted departure from binding authority'. ${ }^{57}$

The second example is constructive dismissal. This term of art applies where the employee is entitled to terminate his contract by reason of the employer's conduct. In the 1970s there were two alternative tests of constructive dismissal. One test was an industrial relations test, which the Employment Appeal Tribunal explained was 'conduct of a kind which in accordance with good industrial relations practice no employee could reasonably be expected to accept ${ }^{58}$. The other test was a common law, contractual test and it was this test that triumphed when it was held by Lord Denning in the Court of Appeal in Western Excavating (ECC) $v$ Sharp ${ }^{59}$ that the test for whether or not there was a constructive dismissal was whether there was a fundamental breach of contract, that is the common law test. 
As well as importing common law concepts and thus becoming legally technical, employment tribunals' procedure has become more formal. One example is the trend away from oral evidence. When employment tribunals were first constituted, parties gave oral evidence. In England and Wales, however, but not Scotland, the practice of preparing and exchanging witness statements in advance became common some dozen years ago. Then in 2012 the Government brought in a rule to require witness statements to be taken as read, unless a judge or tribunal directs otherwise. While legal personnel are trained and accustomed to drawing up such statements for their clients, unrepresented parties may find that daunting when compared with going along to tell their story.

Third, tribunals' discourse has become more technical with legal terms becoming more common because increasingly parties have resorted to representation by lawyers, rather than lay representation or self-representation. Dickens et al ${ }^{60}$ quote a President of employment tribunals in 1971 as saying that tribunals are meant to provide 'an atmosphere in which the ordinary man (sic) feels he is at home ... so that he is prepared to conduct his own case before them with a reasonable prospect of success'. In 197320 per cent of claimants had a legal representative at a tribunal hearing and 37 per cent of respondent employers. In 2013, 33 per cent of claimants and 67 per cent of employers were represented at the full hearing, mostly, although not always, by a lawyer. ${ }^{61}$ Lawyers can mystify the prosaic, or to quote the then president of the Employment Appeal Tribunal, Mr Justice Morison: ${ }^{62}$

There are many traditional dances which lawyers can and do choreograph for performance on the head of a pin, which are designed to induce the audience to believe that black is white...

Not surprisingly given the increasing dominance of legal norms and legal practice, there is evidence that legal representation increases chances of success. For instance 25 years ago, Genn and Genn found that legal representation increased the claimant's chances of success at an employment tribunal from 30 per cent to 48 per cent, where the employer was unrepresented. ${ }^{63}$ Recently, however, Adler found that the representation premium was only 3 per cent. ${ }^{64}$

\section{Expert knowledge}


As we have seen industrial tribunals, as they were then called, were set up under the Industrial Training Act 1964 to adjudicate complaints about levies on employers for training and from the outset they were constituted on a tripartite basis at a time when there was already a long tradition of tripartite structures to resolve employment issues. During World War I there were Munitions Tribunals with a legally qualified chairperson and two wing members, one drawn from a workmen's (sic) panel and one from an employers' panel, essentially to deal with an individual's labour mobility and compensation. Appeals were to the High Court, where at judicial discretion there could be two assessors, worker and employer. ${ }^{65}$ After World War I the Industrial Court was established, though despite its name it was not a court in the usual sense, but rather a standing tripartite arbitration tribunal. ${ }^{66}$ Following World War II, a boost for tripartism as a way of settling employment disputes came from the International Labour Organisation (ILO). In its recommendation 113, issued in 1960, it called on 'competent authorities to seek the views, advice and assistance of employers' and workers' organisations in such matters as the preparation and implementation of laws and regulations affecting their interests' (author's emphasis).

Outside the employment sphere, the presence of expert lay members alongside the legally qualified person is to be found on many other tribunals in the UK including accountants (e.g. the Tax Chamber), someone with a disability (e.g. the Social Security and Child Support Tribunal), a registered medical practitioner (e.g. Mental Health Review Tribunal), a member of the Armed Services (e.g. the War Pensions and Armed Forces Compensation Tribunal), a member who has 'substantial experience of data protection or of freedom of information rights' (e.g. Information Rights Tribunal). Moreover, expert lay members are also to be found occasionally in the court system. For instance the Equality Act 2010 gives jurisdiction to the county court (England and Wales) or sheriff (Scotland) to adjudicate on cases of discrimination in respect of non-employment matters such as services and premises and the judge/sheriff is required to appoint an assessor unless satisfied that there are good reasons for not doing so. ${ }^{67}$ Similarly the Admiralty Court of the Queen's Bench Division of the High Court may sit with assessors. ${ }^{68}$ Where there are assessors, however, they only advise the professional judge, they do not have an equal vote with him/her, unlike lay members in the employment tribunal.

To return to employment tribunals in the 1960s, as noted above, the tripartite tribunals originally comprised a qualified lawyer in the chair and two laypersons, one representing 
employers after nomination by the Confederation of British Industry (CBI) and one after nomination by the Trades Union Congress (TUC) with each of the three having an equal vote. There was a hiatus in 1972 when the TUC asked their nominated lay members to withdraw from employment tribunals as part of the TUC's stance against the Industrial Relations Act 1971 and 80 per cent actually resigned, ${ }^{69}$ but when the Labour government was elected in 1975, the TUC asked its lay members to resume sitting.

When the Labour government fell in 1979, the ensuing Conservative administrations added other nominating bodies including the Union of Democratic Mineworkers, the Council of Managerial and Professional Staffs, the Institute of Directors and the Federation of Small Businesses (Department of Trade \& Industry, 1998). From the outset, however, the TUC and other nominating bodies, however, never sought to influence their nominees or even provide them with training. ${ }^{70}$

When Labour returned to power in 1997 it was concerned to provide more transparency to the selection of public appointees, adopting the so-called Nolan rules. As part of this strategy it ended employer and employee bodies' rights of nomination to employment tribunals and from 1999 lay members have been appointed by an open recruitment and appointment process, not nomination by social partners, with vacancies advertised, applications forms and interviews in accordance with conventional human resource practices. Nevertheless, the Lord Chancellor is still statutorily enjoined to consult organisations representing employers and organisations representing employees. ${ }^{71}$

As to decisions by employment tribunals, a very large percentage of three person decisions were and are unanimous. ${ }^{72}$ Whether one regards this positively as the tribunal acting in a spirit of compromise, or whether one regards it negatively with the lay members becoming quasi-judges, not representatives of a 'side' and unable or unwilling to impose their own views about standards of conduct in the labour market (for instance in respect of unfair dismissal), depends on one's perspective. ${ }^{73} \mathrm{Be}$ that as it may lay members' employment relations knowledge is general and tacit, not particular, as they have never been matched to the sector from which they come and indeed any matching has been criticised by the appellate court ${ }^{74}$. Yet perhaps paradoxically, their presence has often been praised. For instance in a report to the government on the tribunal system Leggatt commented that 
tribunals' decisions 'are the better for that range of skills'. ${ }^{75}$ Similarly, Baronness Hale, a Supreme Court Judge has praised lay members ${ }^{76}$, as has Baroness Ashton ${ }^{77}$.

Praise aside, one must ask what lay members contribute specifically. There is survey evidence that they contribute to the process: providing general workplace experience, giving parties' confidence because decisions are reached by three people, not one, and ensuring a balance between legal and workplace perspectives ${ }^{78}$. Furthermore there is evidence from interviews with the representatives of claimants and respondents that representatives valued their presence because they were able to reassure the parties that it would not just be a lawyer who would be deciding their case $\mathrm{e}^{79}$.

Nevertheless, despite this evidence, lay members have step-by-step been excluded from hearing certain types of cases. Until 1993 the professional judge (that is the legally qualified chairperson) could only sit alone for very limited purposes such as interlocutory matters. Otherwise all matters were determined by a tripartite tribunal (a professional judge and two lay members). The Trade Union Reform and Employment Rights Act 1993 extended the professional judge's power to sit alone to include adjudication on a small number of types of complaint, such as those under the Wages Act, rights on the insolvency of the employer, and those where the parties agreed to that course. Since then there have been further erosions of tripartism, stretching on a piecemeal basis over more than a decade and a half. Thus the professional judge was entitled to sit alone from 1998 to adjudicate on claims for redundancy payments, from 1999 on certain national minimum wage claims and from 2009 on holiday pay cases under the Working Time regulations and stage 1 hearings under the equal value provisions. In addition to the types of cases already mentioned, the professional judge became entitled to sit alone to determine interim relief applications, cases concerning written statements of employment particulars and itemised pay statements, and most recently, in April 2012 to adjudicate on unfair dismissal cases. ${ }^{80}$ As a result of these changes, the professional judge sits alone in over two thirds of all cases. ${ }^{81}$

This is a matter of particular concern in unfair dismissal. In such cases the tribunal has to decide whether the employer treated a potentially fair reason for dismissal as a sufficient reason 'in the circumstances ${ }^{, 82}$. The Employment Judge, however, will usually have little knowledge of the workplace circumstances, unlike the lay members who in the main no longer sit on unfair dismissal cases. The government's justification of the 2012 change was 
financial. ${ }^{83}$ In 1993 the government estimated that lay members cost $£ 5$ million per year, ${ }^{84}$ but it has never been shown what amount of money has been saved by the exclusion of lay members from a jurisdiction.

In addition, all preliminary hearings (formerly Case Management Discussions and Prehearing Reviews) are now normally heard by the legally qualified person sitting alone, and these cover many a preliminary issue, for instance whether a person is an employee and is thus entitled to make a claim of unfair dismissal, whether a claim has been submitted within the time limits, and whether a person has a disability or a religion or belief and can thus claim discrimination on the grounds of one of these protected characteristics.

Meanwhile, the position of lay members has been undermined symbolically by the Tribunals, Courts and Enforcement Act 2007, whereby legally qualified employment chairpersons have been renamed 'employment judges' from December 2007. In contrast, lay members from the outset were often called wing members, that is appendages to the main body, and since 2007 they have been called non-legal members, emphasising what they, unlike employment judges, do not possess. They have not been named lay judges, although since 2007 they have been required to take the judicial oath. ${ }^{85}$

\section{Inexpensive}

One of the distinctive characteristics of ETs and the Employment Appeal Tribunal has been that costs do not follow the event. ${ }^{86}$ Unlike the High Court and most cases in the County Court, a party is not normally awarded costs if they win, nor do they normally have to pay the other side's costs if they lose, but there are exceptions. Before 1980 costs could be awarded by an employment tribunal only if a party pursued a case 'frivolously or vexatiously'. Under Regulations in 1980, the words 'otherwise unreasonably' were added to the test for costs. In 1993, the test for costs was broadened to abusive and disruptive behaviour. In 2001, Regulations further added to the test with the phrase 'otherwise misconceived', although the word 'frivolously' was dropped. In 2013, while the circumstances in which a costs order must be made are unchanged, the scope for a tribunal to exercise its discretion and award costs in other cases could be said to have been increased. Similarly, there have been changes to the amount that can be awarded in unassessed costs: originally $£ 500$, then $£ 10,000$ and since $2013 £ 20,000{ }^{87}$ Nevertheless, costs are only awarded in a minority of cases. For 
instance in 2012-13, costs were awarded from the claimant to the respondent in less than one per cent of claims accepted. ${ }^{88}$

Costs apart, for nearly their first 50 years, claimants could go to an employment tribunal and, if they self-represented, would not suffer any financial loss if they did not win their case. This changed dramatically in 2013 when for the first time fees were imposed and they are hefty. For discrimination, unfair dismissal and whistleblowing claims, the fees at the time of writing (2014) are $£ 250$ to lodge a claim and a further $£ 950$ for a hearing. This, however, is reduced for claims in respect of redundancy payments and unpaid wages: $£ 160$ for lodging and $£ 230$ for a hearing. There is system whereby the fees can be remitted in full or in part, depending on a disposable capital test and a gross monthly income test.

The fees regime has led to a significant fall in the number of claims received: in April to June 2013 (that is before fees were introduced) there were 12,727 individual claims lodged. In April to June 2014 there were 3,792 individual claims lodged, a 70 per cent drop ${ }^{89}$, but the percentage fall varied by jurisdiction, from a 37 per cent reduction in age discrimination claims to 91 per cent in sex discrimination claims, with a 74 per cent reduction in unfair dismissal claims. ${ }^{90}$ Moreover, many claimants do not meet the tests of the remission system. Between July when fees were first introduced and December 2013, just 600 claimants (24 per cent) of those applying for fee remission received all or partial remission. ${ }^{91}$

Employment tribunal fees are more substantial than fees for the small claims court, where the fee depends on the money amount claimed; for instance $£ 105$ for a claim of $£ 3,000$ or less.

\section{Enforcement}

The awards made by employment tribunals are determined by the relevant legislation, whose contents are outside the scope of this article. ${ }^{92}$ Suffice it to say that in the overwhelming majority of cases, if claimants are successful, they are awarded money, but the latest figures indicate that over half of the claimants awarded a pay-out following an employment tribunal hearing do not receive their award in full. ${ }^{93}$

Enforcing awards is often a daunting process as employment tribunals (unlike the small claims court) do not enforce the monetary awards that they make. In England and Wales, individuals can pursue enforcement of their award through applying to their local county 
court for a fee of $£ 40$ for an enforcement order after which enforcement officers will seek to secure payment from the employer. In addition, in 2010, a fast track scheme was introduced to speed up and simplify the process of enforcing employment tribunal awards and Acas settlements by side-stepping the county courts and for a $£ 60$ fee applying to a High Court Enforcement Officer. Research in 2013, however, found that the introduction of the fast track scheme had not led to an increase in the number of claimants pursuing enforcement action. ${ }^{94}$ In Scotland, individuals wishing to enforce their tribunal award need to make an application to the tribunal office for an 'extract' of the award from the Secretary to the Tribunals and instruct the sheriff office to enforce it directly.

\section{Discussion and conclusions}

This article has shown that employment tribunals quickly became very different from other British tribunals in that they morphed from administrative tribunals to bodies adjudicating party versus party disputes like the civil courts. Moreover, although tribunals were characterised 50 years ago as speedy, accessible, informal, expert and cheap, this article has shown how these yardsticks are essentially not applicable today. Compared to when they were established, employment tribunals are no longer cheap, as free access has been replaced by substantial fees to lodge a claim and have a hearing. They are no longer expert: expert lay members originally used to sit at every hearing, but they now only sit at a minority of hearings. They can no longer be described as informal given the increase in case law, legal representation and complex employment law. They are no longer as accessible as they were: long claim forms have replaced simple letters. Moreover, as we showed above, they have moved from the side lines to centre stage in employment dispute resolution, in response to the growth of employment legislation and the decline of regulation by unions and employers jointly. In short, employment tribunals have become juridified over time.

To return to Blichner's and Molander's ${ }^{95}$ five dimensions. The first is constitutive juridification when legal procedures and precise rules are stated, for instance a specified claim form, written witness statements, pre-hearing assessments which were replaced first by pre-hearing reviews and then by preliminary hearings. Their second dimension is when an activity is subjected to legal regulation, for instance laws on redundancy, unfair dismissal discrimination and working time. The third dimension is when conflict is increasingly resolved by law and this article has shown how the number of employment law claims has 
increased. The fourth dimension is increased judicial power and we have shown how lay members, who tempered judicial power, have been eliminated from employment tribunal adjudication. The fifth dimension is legal framing/ a legal culture and we have shown how legal representation has increased, and how industrial relations norms have been replaced by legal norms. Indeed, legal norms have now infiltrated the workplace. For example, the Workplace Industrial Relations Survey 1992 estimates that only eight per cent of 1100 establishments had formal disciplinary and dismissal procedures. ${ }^{96}$ By 2011 , the latest Workplace Employment Relations Survey puts the equivalent figure at 89 per cent. ${ }^{97}$

As noted above, some elements of juridification have been instigated by the government in an attempt to shift some of the costs from the taxpayer to the user, of which the introduction of fees in 2013 is the most egregious example. Other elements have been introduced by the appeal courts, for instance the Court of Appeal's interpretation of the 'band of reasonable responses' test in 2000 and lawyers more generally citing case law. Employers, too, have not been silent as they have called for the weeding out of what they call weaker claims. ${ }^{98}$

Teubner submits that 'juridification is an ugly word - as ugly as the reality which it describes'. ${ }^{99}$ Nevertheless, employers and trade unions do not necessarily agree. In 2001 the Advisory Conciliation and Arbitration Service (ACAS) introduced a scheme to provide arbitration in respect of unfair dismissal as a voluntary alternative. Arbitration is more informal and often speedier than litigation in the employment tribunals; it is confidential, and there is finality as no appeal is allowed. Yet since its inception almost 15 years ago, Acas has only had some 80 cases. ${ }^{100}$ Moreover, in the USA, where workplace arbitration is often used instead of litigation in the courts it is criticised, particularly in non-union settings where the paucity of process regulation can disadvantage the non-represented employee. ${ }^{101}$

This article ends by critiquing the underlining basis of employment tribunals which is that the 'victim' asserts his or her rights to obtain redress after the breach of law has taken place. Such a victim complains approach 'requires certain preconditions: awareness of rights; knowledge of how to enforce them; capacity to claim (including financial capacity) and willingness to do so.' Trade unions can make members aware of their rights and help them to enforce them but, as shown above, unions have declined over the last 30 years. 
Interestingly, the self-help/complainant after the event approach seems to have been accepted without any consideration of an alternative enforcement approach, a state constituted labour inspectorate. Although there are examples elsewhere, for instance in France of labour inspectorates, Britain has never had an overarching one, with several inspectorates established at different points in time and each confined to a specific issue. ${ }^{102}$ Until Britain introduces a comprehensive system of labour inspection, and such an inspectorate is adequately funded, employment rights are unlikely to be widely respected.

\footnotetext{
${ }^{1}$ Heery and Noon, A Dictionary of Human Resource Management, 254.

2 Simitis, 'Juridification in Labour Relations' 113-161.

${ }^{3}$ Masterman, Labour's juridification of the Constitution, 476-92.

${ }^{4}$ Blichner and Molander, 'Mapping Juridication', 36-54.

${ }^{5}$ Department for Business, Innovation \& Skills, 6.

${ }^{6}$ Dickens et al., Dismissed, 9.

${ }^{7}$ Kahn-Freund, Labour and the Law, 9-10.

${ }^{8}$ Department for Business, Innovation \& Skills, 31.

${ }^{9}$ Van Wanrooy et al., Employment Relations in the Shadow of Recession, 58.

${ }^{10}$ Gumbrell-McCormick and Hyman, Trade Unions in Western Europe .

${ }^{11}$ See Simms and Charlwood, 'Trade Unions: Power and Context in aa Changed Context.

12 Smith and Morton, 'Nine Years of new Labour' and 'The conservative Governments' Reform of Employment Law'.

${ }^{13}$ Royal Commission on Trade Unions and Employers' Associations, 155-159.

${ }^{14}$ See Wallington, P. (ed) Butterworths Handbook of Employment Law 2014 for full details current at the time of writing.

${ }^{15}$ See Hepple, chair of Justice committee on Industrial Tribunals, 7. The figure relates to England and Wales only

${ }^{16}$ Harding et al, Survey of Tribunal Applications 2013, 24.

17 Employment Rights Dispute Resolution Act 1998 s.1(1). In Northern Ireland they are still called industrial tribunals.

${ }^{18}$ Clark and Wedderburn, 'Modern labour law: problems, functions and policies', 127-242.

${ }^{19}$ Wedderburn, The Worker and The Law, 264.

20 In France David (1974) cited in Moritz (1987:144) considers that the conseils de prud'hommes were 'a historical achievement' on the part of the trade unions.

${ }^{21}$ An interview with Sir Diarmaid Conroy, President of the Industrial Tribunals England and Wales The New Law Journal, (1970), 19 November 1069-1070.

22 Parliamentary archive 12 December 1963.

${ }^{23}$ See http://hansard.millbanksystems.com/commons/1966/nov/17/industrial-tribunals-selective [accessed 3.12.14].

${ }^{24}$ Employment Department, 8. Renton, 26-27.

25 Wedderburn, The Worker and the Law, 264.

${ }^{26}$ Royal Commission on Trade Unions and Employers' Associations, para 572.

${ }^{27}$ Ibid., para 573.

28 Ibid., para 576.

${ }^{29}$ Meeran, 'The Employment Tribunals', 129-130.

${ }^{30}$ See the report by Franks (chair) Committee on Administrative Tribunals and Enquiries, para 406.

${ }^{31}$ Royal Commission on Trade Unions and Employers' Associations, para 578.

32 Dickens et al., 201. The figure relates to single claims only.

${ }^{33}$ MacMillan, 'Employment Tribunals: Philosophies and Practicalities', 46.

${ }^{34}$ Tribunals Statistics Quarterly January to March 2014.

35 Dickens et al., 205.
} 
36 Tremlett, N. and Banerji, 1992 Survey of Tribunal Applications, 56.

${ }^{37}$ Harding et al., Survey of Tribunal Applications 2013, 75.

${ }^{38}$ MacMillan, 'Employment Tribunals: Philosophies and Practicalities', 35.

39 Employment Tribunals (Constitution and Rules of Procedure) Regulations 2004 SI 2004/1861.

${ }^{40}$ Bowers et al., Industrial Tribunal Practice and Procedure, 229-230.

41 www.gov.uk/government/uploads/system/uploads/attachment data/file/309967/ET1 web 0514 save.pdf [accessed 7 November 2014].

42 Employment Tribunal Statistics 2006-07, 2.

${ }^{43}$ Ministry of Justice statistics 2010-11, Table 1.

${ }^{44}$ Employment Tribunals (Constitution and Rules of Procedure) Regulations 2013 Rule 12b

${ }^{45}$ Hepple and Fredman, Labour Law and Industrial Relations in Great Britain, 62.

${ }^{46}$ Employment Tribunal Constitution and Rules of Procedure 2013. Rule 39

${ }^{47}$ Hepple, Industrial Tribunals, 11.

${ }^{48}$ Wallington (ed) Butterworths Employment Law Handbook

${ }^{49}$ Cook v Thomas Linnell \& Sons Ltd [1977] IRLR 132

${ }^{50}$ Weekes et al., Industrial Relations and the Limits of the Law, 29

${ }^{51}$ Wedderburn, Labour Law and Freedom, 111.

52 Employment Rights Act, 1996, s.98.

${ }^{53}$ W Devis \& Sons Ltd v Atkins [1977] IRLR 314

${ }^{54}$ Iceland Frozen Foods Ltd v Jones [1982] IRLR 439

55 Haddon $v$ Van der Bergh Foods [1999] IRLR 672

${ }^{56}$ Collins, Nine Proposals for the reform of the law on unfair dismissal, 35-36.

57 Post Office v Foley; HSBC Bank v Madden [2000] IRLR 827

${ }^{58}$ George Wimpey \& Co Ltd v Cooper 1977 [IRLR] 205

${ }^{59}$ [1978] ICR 221.

${ }^{60}$ Dickens et al., Dismissed, 73.

${ }^{61}$ Harding et al., Survey of Tribunal Applications 2013, 45.

62 Statement by the President of the Employment Appeal Tribunal The Honourable Mr Justice Morison given on Monday 6 October 1997, unpublished.

63 Genn, H. And Genn, Y. The Effectiveness of Representation in Tribunals, 1989.

${ }^{64}$ Adler http://ajtc.justice.gov.uk/adjust/articles/AdlerTribunalsUsedToBe.pdf [accessed 7.11.14]

${ }^{65}$ Rubin, 'The Origins of Industrial Tribunals', 1977.

${ }^{66}$ Kahn Freund, Labour and the Law, 83

${ }^{67}$ Equality Act, 2010 s.114. It is not clear how such assessors are chosen, but it seems that they are drawn from the tribunals generally, not the employment tribunal specifically.

${ }^{68}$ http://www.justice.gov.uk/courts/procedure-rules/civil/rules/part61\#IDAQXNCC

${ }^{69}$ Wedderburn, Labour Law and Freedom, 295.

70 The author was a lay member of the employment tribunals from 1976 to 1988 and then a member of the Employment Appeal Tribunal and her nomination to both those bodies was through the TUC. In all that time she never received any briefing, communication or training from the TUC in respect of her lay member role.

${ }^{71}$ ET (Constitution \& Rules of Procedure 2013 Regulation 8.

72 For example Selwyn, N. (2008) LAW OF EMPLOYMENT (15th ed) said that 96 per cent of decisions were unanimous although he does not provide any source for the figure that he quotes and a survey by Corby, $\mathrm{S}$. and Latreille, P. (2011) reported that more than 70 per cent of British employment tribunal chairs reported that 70 per cent of their decisions had been unanimous in the previous year. http://www2.gre.ac.uk/about/schools/business/research/centres/weru/publications [accessed 1.12 2013].

${ }^{73}$ Interestingly the government since 1974 has encouraged tribunals when adjudicating on sex discrimination and equal pay claims, to have a woman on the tribunal.

74 In Halford $v$ Sharples [1992] ICR 146, the Employment Appeal Tribunal ruled that on the whole it was undesirable to select members of employment tribunals on the basis of any specialist knowledge that they may have, as their decisions might be informed more by their own knowledge than by the facts and evidence relevant to the particular case.

${ }^{75}$ Leggatt, Tribunals for Users, para 1.2

${ }^{76}$ Gillies v Secretary of State for Work and Pensions [2006] UKHL 2

${ }^{77}$ www.council-on-tribunals.gov.uk/adjust/item/nonlegal2.htm [accessed 8 September, 2014]. 
${ }^{78}$ Corby and Latreille, "'Balance" that Adds Value to Decision Making', 16-18.

${ }^{79}$ Ibid.

80 See Employment Tribunals Act 1996, s.4 for full details of where the Employment Judge (as the legally qualified person is termed) can sit alone and in what circumstances he/she can elect to sit with lay members. In all cases where the professional judge has the power to sit alone there is discretion for him/her to opt for a tripartite tribunal, but anecdotal evidence indicates that the professional judge very rarely exercises this option.

${ }^{81}$ https://www.gov.uk/government/uploads/system/uploads/attachment data/file/218497/employment-tribstats-april-march-2011-12.pdf [accessed 6 November 2014]. More recent TUC estimates, based on Ministry of Justice statistics for April-June 2014 suggest that the legally qualified judge now sits alone in three quarters of all merits hearings/ In other words a tripartite tribunal sit on a quarter of all cases. See http://www.tuc.org.uk/print/120987 [accessed 12 September 2014] and Corby and Latreille (2012).

82 Employment Rights Act 1996 s.98(4)(a).

${ }^{83}$ House of Commons General Committee 21.3.02.

${ }^{84}$ Employment Department, 41.

${ }^{85}$ Carnwath, 'Tribunals and the Courts - the UK model, 8.

${ }^{86}$ Costs are termed expenses in Scotland and there is a Sheriff's Court, not a County Court as in England and Wales.

87 The limit excludes wasted costs (i.e. an order made against a representative as a result of that representative's conduct) where there is no cap.

${ }^{88}$ Harding et al. Survey of Tribunal Applications 2013, 69.

89 Tribunals Statistics Quarterly April to June 2014, 8

90 TUC analysis: www.tuc.org.uk/print/120987 [accessed 8 September 2014]

${ }^{91}$ TUC, At What Price Justice?

92 For instance only in five out of 4,596 (0.1 per cent) of unfair dismissal cases upheld in 2012-13 was there reemployment.

93 Department of Business, Innovation and Skills (2013) Payment of Tribunal Awards

94 Ibid.,

95 Blichner and Molander, 'Mapping Juridication'.

${ }^{96}$ Millward et al., Industrial Relations in Transition, p.213, note 1.

${ }^{97}$ Van Woonroy et al., Employment Relations in the Shadow of Recession, 157.

${ }^{98}$ See for instance British Chambers of Commerce Up to the Job, (2010); Confederation of British Industry (CBI) Settling the Matter (2011) submission to Department of Business, Innovation and Skills.

99 Teubner, 'Juridification, concepts, aspects, limits, solutions, 3.

100 These figures can be gleaned from a careful study of successive Acas annual reports.

101 For more details see Corby and Burgess, Adjudicating Employment Rights: A Cross-National Approach chapter12.

102 See Corby and Burgess, Adjudicating Employment Rights: A Cross-National Approach. For instance, the Health and Safety Executive dates back to 1975, but the enforcement powers of HM Customs and Excise in respect of the minimum wage date back to 1999.

\section{References}

Adler, M. Tribunals Ain't What They Used to Be. 2009.

Blichner, L. and A. Molander 'Mapping Juridification', European Law Journal, 14, 1, (2008), 36-54.

Bowers, Brown, D. and Mead, G. Industrial Tribunal Practice and Procedure, $2^{\text {nd }}$ edition, London: Longman, 1994. 
Carnwath, R. 'Tribunals and the Courts - The UK Model' Canadian Journal of

Administrative Law and Practice 24, (2011) 5-10.

Clark J. and Wedderburn, K. 'Modern labour law: problems, functions and policies in Wedderburn, W., Lewis, R., and Clark, J. (eds.) Labour law and Industrial Relations: Building on Kahn-Freund, Oxford: Clarendon 1983

Collins, H. Nine proposals for the reform of the law on unfair dismissal, Institute of Employment Rights, 2004.

Corby, S. and Burgess, P. Adjudicating Employment Rights: A Cross-National Approach, Basingstoke, Palgrave, 2014.

Corby, S. and Latreille, P. "'Balance" that Adds Value to Decision Making' Tribunals Winter (2011), 16-18.

Corby, S. and Latreille, P. 'Tripartite Adjudication - an endangered species' 43, 2, (2012), 94-109.

Crouch, C. and Farrell, H. 'Breaking the Path of Institutional Development? Alternatives to the New Determinism' Rationality and Society, 16, 1, (2004) 5-43.

Department for Business, Innovation \& Skills Trade Union Membership 2013: Statistical Bulletin, 2014.

Department of Business, Innovation and Skills, Payment of Tribunal Awards, London: BIS, 2013.

Dickens, L. 'The Coalition government's reforms to employment tribunals and statutory employment rights -echoes of the past', Industrial Relations Journal, 45, 3, (2014) 234249.

Dickens, L., M. Jones, B. Weekes and M. Hart Dismissed: A Study of Unfair Dismissal and the Industrial Tribunal System, Oxford: Blackwell, 1985.

Employment Department Resolving Employment Rights Disputes: Options for Reform, Cm. 2707, London: HMSO, 1994.

Erhel, C. and Zajdela, H. 'The dynamics of social and labour market policies in France and the United Kingdom: between path dependence and convergence', Journal of European Social Policy, 14, 2, (2004) 125-142.

Franks, O. Report of the Committee on Administrative Tribunals and Enquiries, Cmnd. 218, London: HNMSO, 1957

Genn, H. And Genn, Y. The Effectiveness of Representation in Tribunals, London: Lord Chancellor's Department, 1989.

Gumbrell-McCormick, R. and Hyman, R. Trade Unions in Western Europe, Oxford: Oxford University Press, 2013.

Harding, C., Ghezelayagh, S., Busby, A. and Coleman, N., Findings from the Survey of Employment Tribunal Applications 2013, Research Series No. 177, London: Department for Business, Innovation \& Skills, 2014.

Heery, E. and M. Noon A Dictionary of Human Resource Management, $2^{\text {nd }}$ ed., Oxford: Oxford University Press, 2008.

Hepple, B. Industrial Tribunals, a report of a committee chaired by Bob Hepple, London: Justice, 1987.

Hepple, B. and Fredman, S. Labour Law and Industrial Relations in Great Britain, Deventer, Netherlands: Kluwer, 1986:

Kahn-Freund, O. Labour and the Law, $2^{\text {nd }}$ ed., London: Stevens \& Sons, 1977.

Leggatt, A. Tribunals for Users Report of the Review of Tribunals by Sir Andrew Leggatt, London: Stationery Office, 2001.

MacMillan, J. 'Employment Tribunals: Philosophies and Practicalities', Industrial Law Journal, 28, (1999) 33-56. 
Masterman, R. 'Labour's juridification' of the constitution' Parliamentary Affairs, 62, (2009), 476-92.

Meeran, G. 'The Employment Tribunals', in Dickens, L. and Neal. A. (eds.) The Changing Institutional Face of British Employment Relations, Alphen aan Den Rijn: Kluwer Law, 2006.

Millward, N., Stevens, M., Smart, D. and Hawes, W. Workplace Industrial Relations in Transition, Aldershot, Dartmouth, 1992.

Renton, D. Struck Out, London: Pluto Press, 2012.

Royal Commission on Trade Unions and Employers' Associations, chaired by Lord Donovan, Report, Cmnd 3623, London: HMSO, 1968.

Rubin, G. 'The Origins of industrial Tribunals: Munitions Tribunals during the First World War, Industrial Law Journal, 6, 1, (1977) 149-164.

Simitis, S., 'Juridification of Labour Relations', in G. Teubner (ed.) Juridification of Social Spheres, Walter de Gruyter: Berlin, 1987.

Simms, M. and Charlwood, A. 'Trade Unions: Power and Influence in a Changed Context, chapter 6 in Colling, T. and Terry, M. (eds.) Industrial Relations: Theory and Practice, $3^{\text {rd }}$ ed, Chichester: Wiley, 2010.

Smith P. and Morton, G. 'Nine years of new Labour: neo-liberalism and workers rights' British Journal of Industrial Relations, 44, 3, (2006) 401-420.

Smith, P. and Morton G. 'The Conservative Governments' Reform of Employment Law, 1979-97: "Stepping Stones" and the "New Right" Agenda', Historical Studies in Industrial Relations, 12, (2001) 131-147.

Teubner, G. 'Juridification, concepts, aspects, limits, solutions' in G. Teubner (ed) Juridification of Social Spheres, Walter de Gruyter: Berlin, 1987.

Tremlett, N. and Banerji, The 1992 Survey of Industrial Tribunal Applications, London: Employment Department, 1994.

TUC At What Price Justice? The impact of employment tribunal fees, London: TUC, 2014.

Van Wanrooy, B., Bewley, H., Bryson, A., Freeth, S., Stokes,L. and Wood, S. Employment Relations in the Shadow of Recession: findings from the 2011 Workplace employment relations survey, Basingstoke: Palgrave, 2013.

Wallington, P. (ed.) Butterworths Handbook of Employment Law, 2014.

Wedderburn, K. Labour Law and Freedom, London: Lawrence \& Wishart, 1995.

Wedderburn, K. The Worker and the Law, $3^{\text {rd }}$ ed. Harmonsworth, Penguin, 1965.

Weekes, B., Mellish, M., Dickens, L. and Lloyd, J. Industrial Relations and the Limits of the Law, Oxford: Blackwell, 1975. 